highlands and lowlands which in one part of their course have cut dcep vertical gorges not unlike cañons, while at another they have scooped out wide open valleys with gently sloping sides, so to come to any conclusion based on the assumption that the eroding action of streams is uniform is very unsafe.

Mr. Browne seems also to take a very peculiar view of the extent of the ancient glaciers, as he speaks of the channel of the little stream he describes as "sufficient to guide the glacier in its flow," seeing that the great glacier which flowed over Scotland from north-west to south-east took no notice of such a channel in its course as the Firth of Tay, but swept over it and the county of Fife beyond, scarcely showing a trace of being deflected at all. Surely there could not be such an enormous difference in the dimensions of the glaciers on the opposite coast as this would indicate. Whatever was the case on Loch Maree, the glaciers that moved down Loch Assynt and Loch Broom were no pigmies.

Newport, Fife, September 27

\section{The Bis-cobra, the Goh-sámp, and the Scorpion}

SNAKES of all kinds are held in great horror by the natives of India, and they slay indiscriminately and ruthlessly all they come across, but this horror pales before the terror inspired even by the names of the bis-cobra and goh-sámp,-terror so great, that, if met with, the harmless animals are given the widest berth possible, and their destruction is never attempted. Though actual animals, they are virtually mythical, that is as regards the deadly properties assigned to them, and we easily recognise in them the originals of the flame-breathing dragon and deadly basilisk. The gaze of the bis-cobra is awful even from a distance and its bite is instant death; and if the goh.sámp breathes upon, or at you, you fall dead at once.

With such awful reputations attached to them, I lost no time, in my early career, in attempting to make the acquaintance of these formidable reptiles, and, after much labour, succeeded.

No one would help me in procuring a bis-cobra, and my servants repeatedly warned me against the risk and madness of the attempt. At one time I had engaged the services of a savage woodsman in collecting birds' eggs, and to him I, one day, applied for a bis-cobra, but he at first refused, and it was only the promise of large bakhsheesh that ultimately induced him to promise his assistance. After several days he appeared carrying an earthen pot at the end of a long bamboo, and meeting me, whispered mysteriously in my ear "Sahib! bis-cobra!" Glad of the news, I summoned my servants, who, when they heard the reason of the summons, reluctantly formed a distant semicircle. The pásee cautiously put down the pot and also retired to a distance. In no way dismayed, I approached the pot, removed the dirty rag around its month and looked in. As expected, I found a beautiful brown and yellow lizard, freely protruding in its fear a forked anguine tongue, and anxious to escape. On taking it up it seized my hand with its delicate teeth, and in this position I held it up to the horror-stricken servants who exclaimed in fear "Sahib! sahib! chōr do, phenl do (Master! master! let (it) go, throw (it) away)." Then, on my declining to do either, they, like the barbarians of old, waited anxiously to see whether I "should have swollen or fallen down dead suddenly," and, seeing no harm, they quietly dispersed.

My adventure with the goh-sámp was unsought and equally satisfactory.

Walking in my garden one day, $I$ met the gardener rumning away with affrighted look from a pear tree, and asked the reason; he could only gasp out "Goh-sámp, sahib, goh-sámp!" and implore my return. Delighted at the opportunity, I pressed on, and soon saw the awful reptile trying to dodge my gaze; a large scaly, uncanny looking tree lizard about fourteen inches long. In the distance the mali (gardener) implored 'me to beware his "phoonk" (blast of breath), but I courted it, by trying to dislodge him, which I succeeded in doing by shaking the bough, and then he threw himself on the ground and scuttled up another tree, Both lizards are absolutely harmiess, and I believe a poisonous lizard is quite unknown.

The scorpion is not dreaded like the snake, but, like it, is inevitably killed. Its habits and pursuits well deserve study my observance of the former has enabled me to clear away (to my own satisfaction) many obscurities with regard to its poison weapon and the mode of using it. And let me declare at once that the popular idea regarding scorpionic suicide is a delusion based on impossibility. Owing to the position and nature of its weapon, the animal cannot strike itself. It does not protrude a sting as bees, $t$ t hoc gemus omne, do, and the line of strike is downwards and backwards, with at times a lateral but yet downward motion. As literally described in Holy Writ, it strikes but does not sting; and its motion in so doing may be imitated by seizing the tip of the index or middle finger with the thumb, and suddenly liberating the former.

The poison is acid and albuminous; the latter I presume, as on placing a living specimen in spirit, the animal in its death throes ejected it, and it immediately coagulated in threads.

The pain and constitutional disturbance attendant on scorpion strike are often very severe, and children have occasionally succumbed ; but adults only complain of the pain, which generally passes off in half-an-hour. On two occasions I have passed through a host of migrating crickets, once by day and once by night; on the first occasion my carriage wheels crunched for a mile through a cricket migration; and on the second my palkee bearers' feet slid about amid crushed crickets; on this occasion one of the bearers yelled out that a scorpion (out on a cricket spree) had struck his foot, and hobbled up to the palkee. Having the means at hand I. applied a paste of ipecacuanha and laudanum, with almost immediate relief, and the bearer trudged on with the rest.

Peshawar

\section{H. F. HUTCHINSON}

\section{Certain Animal Poisons}

I HAVE had unpleasant experiences of the poisonotis properties of the Portuguese man-of-war, the great hornet, and the centipede.

While bathing at the Cape as a boy I managed to get the long lovely blue tentacle of the first round my wrist, and well recollect the attendant long-enduring agony and irritation, while the blute mark remained long on my wrist. Twenty-five years after, while soaking in a $\mathrm{P}$. and $\mathrm{O}$. steamer's marble bath in Madras roads, I suddenly receiveid what seemed an agonizing stab below my left knee, and jumped out of the bath with the pain. The cause was at once apparent, a bit of theifatal blue filament bad been pumped into the bath, and left the familiar mark on my knee, and I bore it for a long time.

On one occasion I was showing some friends over the famous "Arrah House" and opened a small window to let in more air and light; in doing so, I unwittingly disturbed the adhesions of a great hornet's nest, and one of the infuriated inmates at once stung me on the left temple; the pain was intense and the swelling immediate; aware of the constitutional disturbance which would follow, I made for home (about 500 yards dis tant), and reached the threshold of my drawing room, and there I was brought to an instant standstill, unable to move hand or foot, and trembling like an aspen leaf. I was laid on a sofa, and asked for a glass of port wine, which soon revived me.

This dreadful hornet, nearly two inches long, deep brown with a broad yellow band across the abdomen, builds large globular paper nests, and is not rare in the Himalayas, where it may often be seen in the pines. The hillmen dread it extremely, and with good reason, for a swarm, or even a few individuals will attack you fiercely and follow you for miles.

Griffs, who have fired at a nest, against the remonstrances of their hillmen, have paid dearly for their rashness. When at tacked, the hillmen squat down and drawing their blankets closely around them, await the subsidence of the storm, rarely escaping two or three stings. I have known one of these hornets kill a child by its sting ; and many horses have been destroyed by an infuriated swarm. These are the dreadful animals which assisted in the expulsion of the Amorites of old

The common bee, which in India often builds in trees and ruins, frequently attacks men and horses, irritated by the smoke of the fires (for cooking) lighted under the trees or in the build. ings, and a general sauve qui peut is the only mode of escape.

Many ludicrous adventures occur from this cause out here, and $I$ will describe a recent one. The officers of a British regiment stationed at Umballa were dressing for Sunday morning Church parade, when the alarm was given in the compound of three who lived together, that the bees were abroad. As escape from the parade was impossible, and the infuriated bees had to be faced, the three griffs made a syce (horse attendant) envelope himself in a blanket, while each wrapped a sheet around himself, and then formed a line, the front officer holding on to the syce's bamboo, and the other two to one another's swords, and in this guise they groped their way out of the compound surrounded by 